\title{
Traditional Authority at the Crossroads of Governance in Republican Cameroon
}

\author{
Cosmas Cheka*
}

\begin{abstract}
The study shows that traditional authority is indeed at the crossroads of governance in republican Cameroon. The citizen is bound by both modern law and traditional values; even if political theorists and leaders of republican institutions take objection to certain traditional values and seem to find difficulty over whether/how to formally integrate traditional authorities into the realm of the republic. Traditional authority incarnates a reassuring institutional stability and certainty to the masses, which elected officers (who come and go) do not provide in republican institutions. The vast majority of the population feels distant from the concept of 'republic' at grassroots level, where traditional authority remains the de facto institution of local governance. Based on empirical findings that highlight the important role that traditional authorities play in local development, the paper submits that traditional authorities should be formally integrated into the republican institutional setting by effectively constituting the first level of decentralized institutions of governance.
\end{abstract}

\section{Résumé}

L'étude montre que l'autorité traditionnelle est véritablement à la croisée des chemins de la gouvernance au Cameroun républicain. Le citoyen est interpellé aussi bien par la loi moderne que par les valeurs traditionnelles; même si les théoriciens politiques et les responsables des institutions républicaines émettent des objections à l'encontre de certaines valeurs traditionnelles et semblent avoir des difficultés à admettre la question de savoir s'il faut et comment intégrer de manière formelle les autorités traditionnelles dans le sphère de la république.

* Senior Lecturer, Faculty of Law and Political Sciences, Yaoundé University II at Soa, P.O. Box 7814, Yaoundé, Cameroon. E-mail: ccosmas4@yahoo.com 
L'autorité traditionnelle incarne une stabilité institutionnelle rassurante et une certaine constance aux yeux des populations, ce que les officiels élus (qui vont et viennent), ne parviennent pas à assurer dans les institutions républicaines. La grande majorité de la population se sent très éloignée du concept de la 'république' au niveau des masses où l'autorité traditionnelle demeure, de facto, l'institution chargée de la gouvernance locale. Se fondant sur des résultats empiriques qui mettent en exergue le rôle important que les autorités traditionnelles jouent dans le cadre du développement local, le document soutient que ces dernières devraient être formellement intégrées dans l'arène institutionnelle républicaine, constituant ainsi de façon effective le premier échelon d'institutions décentralisées de la gouvernance.

\section{Introduction}

With the end of the Cold War, 'governance' for the first time prominently overshadowed democracy in international development, academic and policy discourse. Development assistance is increasingly made conditional upon fundamental reforms in line with donor perception of 'good governance'. Governance is indispensable in enhancing the effectiveness of government operations and in stimulating private investment and, therefore, growth. In African society governance is mirrored by at least three blocs of institutions: the traditional, religious and republican (Elong Mbassi 1994: 15). Collectively these stakeholders, the republic (or republican institutions), religion and traditional authority, ensure governance. Unlike the democratic agenda, which excludes some actors on the grounds of principle, governance theory is inclusive of all stakeholders (UNDP 1995, 1997). When in the late 1980s and early 1990s, international development discourse predicated development on democracy, the undemocratic tenets of traditional authority were highlighted as the reason for their being sidelined by modern institutions. This came to add to the ravages that had been dealt to this institution by colonization and postcolonial strategies in favour of institutional hegemonization built around republican values. The consequence of this was the clear 'creation of two publics' (Ekeh 1977), 'as one of the lasting legacies of colonialism' (Osaghae 2006: 237), and the laying of the foundation for 'citizen and subject' (Mamdani 1996). Applying republican principles, there would be elections that result in a winner who represents citizens (the civic public) in civil society and dominates subjects through the appointment of traditional authorities (the primordial public). At the dawn of the new millennium and with the accent of policy discourse on governance, one key pro-active issue was the identification of actors in the governance process to include (even if generally characterized with civil society), traditional authority. The relevance of this topic, therefore, arises from the apparent interest manifested by the 
government of Cameroon itself, in the adoption of a National Governance Programme in 1998.

Traditional authority predates colonization. At independence it has imaged itself as a 'symbol of tradition' while at the same time striving to serve as an agency for 'modern projects' (Geschiere 1993: 152). The postcolonial difficulties and mutations of traditional authorities or chiefdoms have indeed constituted the subject of vast scholarly interest, and traditional authorities have in the process served diverse purposes. By indirect rule, for example, the British sought to borrow legitimacy from traditional authorities for the implementation colonial policies (Jua 1995: 41, 43). Again, chiefs appointed as Native Authorities in the Bamenda region of Cameroon were empowered to collect tax revenue within their jurisdictions for expenditure by colonial masters, and, on their advice and under section 40 of the Federal Constitution of Cameroon of 1961, they were constituted into the now-disbanded House of Chiefs (Jua 1995: 39). With the advent of democracy, traditional authorities have served as 'vote banks', especially in one-party states (Fisiy 1995; Nyamnjoh 2002) and as members of the 'Land Commission' on the strength of section 12 of Decree No 76-166 (27 April 1976) establishing terms and conditions for the management of national lands.

Modernization theorists in the decades following the Second World War predicted that traditional authority would soon become outmoded and be replaced by 'bureaucratic offices and institutions' (see, for example, Balander 1972: 159ff.; Warnier 1993: 318; Harniet-Sievers 1998: 57; Kamto 1999: 201). Other social scientists have, on the contrary, praised its remarkable powers of survival (Fisiy 1995: 50), and as 'a dynamic institution, constantly re-inventing itself to accommodate and be accommodated by new exigencies' (Nyamnjoh 2002: 8). Scholars are of the view that in the governance era, 'the level of power the chiefs can exercise will be determined by their level of collaboration with those who hold the reigns of power - the state elite' (Fisiy 1995: 59), and by 'anticipation of or failure to attract state-driven development efforts in their chiefdoms' (Nyamnjoh 2002: 6).

Based on the submission that traditional authorities are stakeholders in the governance process, this paper departs from the sterile debate of traditional authority as a dying institution (or not) to propose that it exposes the positive role that traditional authorities today play in development as institutions, which justifies their integration into republican institutions rather than being left on the periphery.

In Cameroon today, traditional authority is exercised at the grassroots level and is governed by decree No. 77/245 of 15 July 1977 organizing the chiefdoms. This has not always been so. Prior to independence, the present Cameroon was made up of centralized societies in especially the grassfields 
(such as Bamenda and the present Northern provinces) and acephalous groupings in the southern part of the country. In fact, powerful and centralized chiefdoms (traditional authority) in the Bamenda region of Cameroon date back over 400 years (Nyamnjoh 2002). These were not dismantled by the British colonial policy of indirect rule. By contrast, in the segmentary southern half of the Cameroonian territory, a region without a tradition of central government, the French colonial masters created 'warrant chiefs' (Le Vine 1964; Gardinier 1963) and sought to reform it (Le Vine 1964: 97-8) by Order No. 224 of 4 February 1933 defining the status of indigenous chiefs. Though the earlier cited 1977 postcolonial decree is said to mark 'the gradual bureaucratization of the institution of chieftaincy' (Fisiy 1995: 59), it is significant that today all traditional authority in Cameroon is subject to uniform legislation. Especially, it is submitted that this 'uniformization' renders findings of studies on traditional authorities in centralized chiefdoms useful to the same authorities created by law in the acephalous parts. Cameroon has, however, been undergoing institutional reform since Law No. 96/06 of January 1996 introducing the new Constitution. In its section 55, the latter Constitution ushered in decentralization whereby the decentralized authorities would be regions and councils. The latter structures are mainly charged with the task of local development under section 4(1) of Law No. 2004/17 of 22 July 2004 on the Orientation of Decentralization. The constitutional provision is silent on any consideration of traditional authorities (organized by law) as decentralized bodies. Also, traditional authorities do not formally constitute part of the deconcentrated institutions of the republican administrative machine that is made up of divisions and subdivisions. They simply are 'traditional authorities', albeit stakeholders in governance.

\section{Methodology}

The analysis is descriptive. Primary data is drawn from a pilot study conducted in the first quarter of 2007. Secondary data is based on a review of the works of social scientists, and the examination of the laws on traditional authorities in Cameroon. The primary data was collected through a questionnaire survey of 100 persons of both sexes aged 20-79 in the Tubah Municipality in the North West Province of Cameroon.

This region of Tubah, although neither very cosmopolitan nor multi-ethnic, can be considered a microcosm of the nation. It is a microcosm in the sense that key actors in development and leadership here epitomize the changing dynamics of the nation. Traditional authority is present albeit centralized. A local council that constitutes the decentralized modern authority is present. Nevertheless, unlike former times when the latter had no direct responsibility for local development, the law now endows them with the said duty. To 
complicate matters, councillors are largely retired civil servants who have spent the most of their working lives out of the area. They need to connect to effective local power to carry out meaningful developmental change. They need the clout of local authorities for them to use their knowledge of republican values to effect change at grassroots level.

Respondent groups involved in the study were split into modern authorities (councillors and members of parliament), traditional authorities and commoners. Of these $51 \%$ were male and $49 \%$ female; all of them were indigenes. Of the commoners, $44 \%$ had no formal education while $56 \%$ had at least primary education. Determination of who participated in the survey was through a structured sample to ensure proper representation. The purpose was to elicit and determine through the collected data whether there is a nexus between governance and traditional authority within a republican framework. Information was therefore gathered from the target groups in the sample with emphasis on the role of traditional authority as perceived and lived by modern authorities, commoners and traditional authorities themselves through questions touching on their job description, the place of traditional authorities in their activities, issues over which modern authorities consult traditional authorities, and whether this consultation is mandatory or discretionary. Questions were also asked about the nature of the relationship between modern and traditional authorities and whether this enhanced or hampered their work for development, and if modern and traditional authorities could and should co-exist. Secondary data was collected through documentary research, which sought to highlight whether/how and if at all traditional authority is integrated in the governance machine of the republic, considering the role of the former in the life and essence of the latter.

The concepts of 'republic', 'governance' and 'traditional authority' are central to the analysis. 'Governance' is a commonly used word but it has been described as a 'plastic' concept (Jenkins 2002) because it is complex and difficult to define. 'The republic is a vision, a conception of the world, where the people - and no more the king - are sovereign' (Kamto1999: 181). 'Traditional authority' is subject to diverse definitions. It might therefore be useful to briefly circumscribe the conceptual framework on which the paper builds before reverting to empirical findings that buttress its argument.

\section{Conceptual framework}

\section{Traditional authority}

Chambers Twentieth Century English Dictionary defines the noun 'tradition' as handing over, oral transmission from generation to generation, anything bound up with or continuing in the life of a family or community etc. It 
defines an 'authority' as 'a person or body holding power or right, permission derived from office or character' More specifically, according to Osborn's Concise Law Dictionary (1976: 40), 'authority is a body charged with power and duty of exercising prescribed functions'. Traditional authority as such refers to an institution or power that is received and handed down or over from generation to generation. It is arguable, however that this definition captures the current meaning of those two words because in Cameroon traditional authorities must also have the benediction of public authority to legally wield power, right and prescribed functions.

Max Weber (Extracts: 328) perceives traditional authority from the perspective of legitimacy; whereby acceptance of the right to rule is based on tradition or custom. To some scholars, 'traditional authority' is synonymous with traditional chiefdom/rulership. These experts argue that the adjective 'traditional' should not be understood as hitherto defined because, it was used by colonial masters to contrast with the modern powers that they represented. Its connotation is therefore, denigrating. For example, Joseph Mboui ${ }^{1}$ states that 'the use of the term "chief" (authority) instead of "king" by the colonial masters was meant to denigrate African rulers'. Crowther and Ikime (1970: 9) also assert that the word 'chief was a distinctive diminutive colonial term meant to reduce the status of great African Kings like the Obase of Benin, who in colonial times considered themselves and were considered by their people as "Kings".

For the purposes of this study, traditional authority whether created by law, in centralized or in segmentary societies, is a power, or permission, an institution that draws its legitimacy, whether wholly or partially, from tribal/ ethnic/cultural values of a group of people (wherever they may be) that share them. Traditional authority therefore contrasts with that based on republican values of accession to power by, say, the application of a constitution, which, for example, embraces democratic principles. The republican mode enables the creation of powers and institutions for which accountability is owed to the electorate, unlike the traditional ruler who is largely accountable to a traditional council of notables and to his subjects. It has to be understood that this dichotomy results from migration and interaction of people of various ethnic backgrounds who have to live together in a common geographical environment.

\section{The republic is a vision of the world}

A republic is not a particular form of government. Political theorists, both ancient and modern, are of the opinion that 'republic' refers to what ought to be the character and business of government. According to Thomas Paine (1792: 88), 'It is wholly characteristical of the purport, matter or object for 
which government ought to be instituted, and on which it is to be employed, Res-Publica, the public affairs, or the public good; or, literally translated, the public thing.' 'Republic' is 'naturally opposed to the word monarchy, which has a base original signification. It means arbitrary power in an individual person; in the exercise of which, himself, and not the res-publica, is the object.' ${ }^{2}$. In American constitutional theory, James Madison (1787) states that the republic is a political regime or form of government, 'in which the scheme of representation takes place'. To the French constitutional theorist Benjamin Constant, 'all governments - constitutional monarchy, republic or empire - are acceptable so long as they respect fundamental rights'. ${ }^{3}$ Maximillien Robespierre (1791) is of the view that 'the republic is any state governed by law without any form of administration for it to be, because the public interest simply governs'. ${ }^{4}$

Modern academic writing on 'the republic' generally highlights the nonhereditary character of the head of state, representation - of sovereign people - and the fact that the latter is the very essence that enhances and ensures the common good that is the end of power. To the Roman political theorist, Slim Lagmani (1994), ${ }^{5}$ the election of those who govern is the sole mode of designation that gives meaning to sovereignty of the people, enabling the realization of the end of politics: the common good. The republic, in one breath, apparently is the state, system of government and mode of designation of the head of state.

The modern republic is therefore one that has the public interest as a core value, with others being liberty, sovereignty, representation, equality of all before the law, separation of powers - state/religion, citizenship referring to the holder of rights and obligations. In theory, therefore, every government that does not act on the principle of a republic or, in other words, that does not make the res-publica its whole and sole object, is not a good government. Republican government is no other than government established and conducted for the interest of the public, as well individually as collectively. In fact, Thomas Paine (1792: 88) asserts that it is not necessarily connected with any particular form, but it most naturally associates with the representative form, as being best calculated to secure the end for which a nation is at the expense of supporting it.

The African republic is a particular case, owing to African nations being at the crossroads of cultures and values that are African and yet must stay abreast with modern as well as universal political cultures. Against a republic nurtured by an ethic as is the case in the West, African republics have to reconcile their multiple cultures and ethnicities (on which patterns of the exercise of power in Africa are built) with the universal political values of developed nations. This disfigures the classical republican concept to the 
extent that it is now argued by Kamto (1999: 201) that African cultural values be severed from republican precepts because

the republic is political whereas ethnicity is socio-cultural and historic ... African monarchies/traditional authorities have only survived by becoming a place of cultural reference, identity assembly points or structures of its members ... Traditional authority is condemned to disappear ...

As concerns Cameroon, it is difficult not to take objection to Kamto here. For one thing, the roots of traditional authority are generally ethnic and/or cultural, and do not dilute the fact that 'authority' has to do with power and therefore is unavoidably 'political'. Secondly, the end of traditional authority is the 'public good' as res publica means. In the centralized societies of the grassfields of Cameroon, traditional authority has survived colonial and postcolonial attempts to relegate it to the pile of dead institutions because it plays a positive role in governance. In a nation that is essentially a collection of ethnic groups, traditional authority is the foundation of governance to most people.

It must further be clear here that the analysis has evolved to a perception and acceptance that African political and governance institutions are alive and with us. The question hence is and should be whether, and by how much, they serve the public good.

\section{Governance is the manner in which power is exercised for development}

The market-oriented view, championed by the World Bank (1992), is to the effect that governance refers to 'the manner in which power is exercised in the management of a country's economic and social resources for development'. Policy advisers and specialist institutions often use governance as a qualitative term for describing the administrative effectiveness and efficiency of state institutions (Beall 2005). Similar views of governance have been expressed by UN ESCAP (2004), that governance is 'the process of decision-making and the process by which decisions are implemented (or not implemented)' (UNDP 1995 1997), that governance is 'the set of values, policies and institutions by which a society manages its economic, political and social affairs through interactions among the government, civil society and private sector'. UNDP also defines governance as the exercise of political, economic and administrative authority in the management of a country's affairs at all levels. For USAID, governance is 'the effective management of public affairs through the generation of a regime (set of rules) accepted as legitimate, for the purpose of promoting and enhancing societal values sought by individuals and groups' (Hyden et al. 2005). 
Added to this multitude of governance systems is the notion of ' $g o o d$ governance', which now is a general guiding principle for major donor agencies in the distribution of development and relief assistance. UNDP defines good governance as governance that is effective, participatory, transparent, accountable, equitable and promotes the rule of law. Particularly important in the context of countries that are institutionally weak is the fact that UNDP's definition of good governance encompasses not just the state but the private sector and civil society as well. All three are viewed as critical for sustainable human development. The role of the state is viewed as that of creating a stable political and legal environment conducive to sustained development, while civil society institutions and organizations are viewed as a means of facilitating political and social interaction and mobilizing groups to participate in economic, social and political activities.

The World Bank describes good governance as 'central to creating and sustaining an environment which fosters strong and equitable development, and is an essential complement to sound economic policies' (World Bank 1992). Good governance is 'epitomized by predictable, open, and enlightened policy making (that is, transparent processes); a bureaucracy imbued with a professional ethos; an executive arm of government accountable for its actions; and a strong civil society participating in public affairs; and all behaving under the rule of law' (World Bank 1994). This rather normative concept identified a group of policy ideas that were seen as a model for effective economic and political management (Beall 2005). It includes characteristics such as: participation, rule of law, transparency, responsiveness, consensus orientation, inclusiveness, effectiveness and efficiency. Good governance is in general a highly technical and institutionally orientated approach towards governance that owes more to public administration and management than it does to political theory. ${ }^{6}$

Policy literature concerned with local governance is mainly focused on the theme of decentralization. It is seen as an important component of the good governance model, and it serves as the dominant overarching analytical and policy framework towards local governance. The concept of decentralization refers to the general process of 'transferring political and administrative authority to sub-national government bodies' (Sisk et al. 2001). Political science theorists have differentiated four major types of decentralization: deconcentration, delegation, devolution and privatization, all referring to deferent levels of power and resource transfers (Cheema et al. 1983). It is believed that this type of government can improve governance by fostering accountability, transparency, efficiency, improved service delivery and popular participation (Martinussen 1997). 


\section{Governance is also a way in which power relations are structured in society}

The society-oriented thinking on governance has largely been concerned with developing a better analysis and understanding of the different state/ society relations. Governance is not seen as a set of technical functions but as a way in which power and authority relations are structured in various societal contexts (Doornbos 2001). Society-oriented theorists like Jenkins (2002) are of the view that governance refers to the 'prevailing patterns of the exercise of power in a given society'.

Peter Evans et al. (1985) emphasized the state's autonomous position in society and its central and powerful role in shaping people's behaviour. Joel S. Migdal $(1988,2001)$, however, challenges the forgoing state-centred view, noting that states have been in general successful in penetrating society but failed in effectively changing population's behaviour and regulating social relations. For example, the present pilot study demonstrates that the citizen in Cameroon out of fear in one case or willingly in the other, subjects himself to two types of orders: modern and traditional. To understand this, it is important to acknowledge that states have an impact on societies, and societies also impact on states.

The governance premise that underlies the present analysis is that of a traditional authority of centralized society origins (or not) with a common culture and ethnicity as its basis. It is a legitimate model of the exercise of power at grassroots level at the service of the people. In modern terms, traditional authority in this paper is a model that combines both the marketoriented definition (with the efficiency and efficacy connotations included and subsumed in good governance) and its society-oriented meaning (i.e. traditional authority is an integral part of institutions that regulate social relations). These connotations are highlighted by the findings of the pilot study, which make the case for formally involving traditional authority in the management of the affairs of the republic. Traditional authority, like republican authority, serves the common good. The law half-heartedly organizes and endows traditional authority with roles (as the role/legal framework shows); yet traditional authority seems to be unavoidable in matters of effective local development.

\section{Role/legal framework of traditional authority}

The legal framework is set by the earlier-cited decree of 1977, which recognizes and assigns roles to traditional authority. Yet academics and the Cameroonian legislator are at odds with each other as to the role of traditional authority today. Academics see the role as a negligible one. To Nack Mback 
(2000: 84), 'traditional institutions have lost their role as a check on the powers of modern institutions and have been relegated to the rank of mere consultative organs'. Traditional authorities, to Kamto, are 'a place of cultural reference: structures where members gather together to project a common identity. Traditional authority is condemned to disappear by obliteration as was the case with Sekou Touré's Guinea should it engage in political competition or power play with the State' Kamto (1999: 201). To the legislator however, traditional authorities have a role that surpasses that of a mere 'place of cultural reference'. Chiefs are organized into and identified with 'territory', and traditional authorities are 'auxiliaries of the administration'.

\section{Chiefs are organized into and identified with territory}

The 1977 decree organizes traditional chiefdoms on a territorial basis following a pyramid of three, the highest of which is the First Class chiefdom. This legal instrument represents a verbatim taking over (Nkwi 1976, 1979; Nyamnjoh 1985; Mouiche 1992, 1997) of legislation on the same subject under French colonial administration (Order No. 224 of 4 February 1933 defining the status of indigenous chiefs). ${ }^{7}$ The First Class chiefdom is one whose area of jurisdiction covers at least two Second Class chiefdoms and its territorial boundaries do not in principle exceed those of a division. A Second Class chiefdom has jurisdiction over at least two Third Class chiefs with boundaries that must not exceed those of a sub-division. A Third Class chiefdom corresponds to a village or a neighbourhood in rural areas and in urban areas. It has been suggested that the legislator's attempted attachment of traditional rulers to 'territory' is intended to confine the ambit of their powers to subjects in identifiable and predefined geographical areas (Nack Mback 2000: 84).

The attachment of traditional authority to 'territory' is intriguing when considered within the context of decentralization and the effective governance role that these authorities play. Most specifically, the decree would seem to be out of sync with the ambit and the realities of the exercise of traditional authority. First, in the grasslands of the English-speaking provinces of Cameroon, for example, traditional authorities were Fondoms (chiefsdoms). These Fondoms still exist today. The Fon is the paramount head of a community of values, customs and of a shared history with others (wherever they may be) in spite of the subjects being part of a nation. Territorialization of fondoms seems to smack of a misunderstanding of the ambit of the powers that traditional authorities wield over their subjects. The authority of the Fon is not limited to the 'territory' where his throne is found or where the majority of his subjects live. The Fon's authority pursues his subjects wherever they may be! 
Moreover, recent institutional reform (as recorded by the Constitution of $1996^{7}$ ) does not repeal the 1977 decree organizing chiefdoms. Under section 1(2) of the Constitution of 1996, Cameroon is a unitary decentralized State made up of administrative units that are deconcentrated into divisions, subdivisions and districts at grassroots level and of local authorities that are decentralized into regions and councils (section 55). So, though the decree of 1977 attaches traditional authority to 'territory' and the latter are considered prior to 1996 as 'auxiliaries of the administration', it would appear that after that date, they are neither obvious decentralized institutions of local governance nor are they formal arms of deconcentrated administrative units. So the apparently flawed 1977 organization of chiefdoms by 'territory' remains.

It is submitted that if 'territorializing' traditional authority to a community was a deliberate attempt by the legislator to confine these authorities to identifiable and predefined geographical areas, the attempt failed because the authority of chiefs is extraterritorial, by mere dint of the fact that the said authority attaches to his subjects wherever they may be. It is now arguable that it might have been an appreciation of the extraterritoriality of the tentacles of power of traditional authority that put off the legislator from regulating it at all in the Constitution of 1996 and formally bringing it within the realm of modern institutions of governance - thus neither killing traditional authorities as institutions nor reforming them. Yet traditional authorities still exercise the governance roles they were cast into by the decree of 1977 .

\section{Accession to traditional authority is hereditary}

The decree of 1977 is to the effect that: 'Chiefs are in principle chosen from among families called upon to exercise traditional customary authority' (section 8 of 1977 decree). By this provision too, candidates must inter alia 'as far as possible, know how to read and write'. As in other African countries such as Mali (Beridogo 1997), the latter requirement has the implicit effect of modernizing and widening the circle of those who are eligible to accede to power under an otherwise hereditary method of succession. The choice of the successor from the candidates presented is made by the modern administrative authority responsible for the 'territory' concerned. The said choice is made after 'mandatorily' consulting with the competent Council of Elders (known as the Kwihfoyn in Tubah and Kom, kwifo' in Bafut, Ngumba in Bali, or Ngwerong in Nso) in a public meeting presided over by the competent administrative official (sections 11, 12). In the case of a First Class Chief, the eventual appointment is made by the Prime Minister and by the Minister in charge of traditional authorities in the case of a Second Class Chief. The competent senior divisional officer appoints Third Class Chiefs (section 15). 
Petitions against the choice and appointment of a traditional ruler are addressed to and heard by the authority vested with the power to appoint. The latter has the last say in the matter (section 16 (1).

Against this provision, respondents to the pilot study charged that one major weakness of Cameroonian republican institutions today is the absence or ineffectiveness of its instruments of accountability: "why endow this official with final powers of appointment when the efficacy and accountability of his institution is questionable and blamed for graft?' they ask. But Ekeh (1975: 100) rationalizes this trend when he states that the

native sector has become a primordial reservoir of moral obligations, a public entity which one works to preserve and benefit. The Westernized sector has become an amoral civic public from which one seeks to gain, if possible in order to benefit the moral or primordial public.

Nevertheless, it is significant that today, both the Council of Elders who indeed are the custodians of local laws and customs (subjects who are said to master the instruments of local governance) and republican administrative authorities are involved in the appointment of the traditional authority.

The hereditary nature of accession to traditional authority does not augur well for the republican values of governance whereby, under the preamble of the 1996 Constitution, 'all men are born equal without distinction of race, religion, and sex and are endowed with inalienable rights' and as such, accession to power is via democratic elections. This view is buttressed by political theory. Thomas Paine (1782: 86), states that 'The hereditary system is as repugnant to human wisdom as to human rights, and is as absurd as it is unjust.' Nevertheless, $91 \%$ of commoners involved in this study state that succession to the throne is and should remain the prerogative of the ruling family 'because custom says so'.

The Cameroonian legislator and the executive have both attempted to bring traditional authority into the realm of republican institutions. First, Parliament has demonstrated a desire to maintain the status, for the time being, of traditional authorities - in spite of the need to modernize. In matters of legislation concerning traditional authorities, members of Parliament were issued with a directive (Cameroon National Assembly Report 1979), that: 'caution be exercised so that Western ideas are not superimposed hastily in this very sensitive area where ... customs are still very rich and varied' ${ }^{8}$ This Legislative caution does not, however, mean that the Cameroonian Executive approves of the hereditary nature of traditional power. In a bill tabled by the government before parliament in 1979, the Executive argued that 'traditional chieftaincy is now a public institution ... and as such must not be handed down by a will'. 


\section{Administrative authority and the Council of Elders choose traditional rulers}

The Council of Elders is usually made up of subjects of integrity and objectivity who have distinguished themselves in one way or another and have been recognized as such by the traditional ruler. Respondents state that access to the Council of Elders is also in $22 \%$ of the cases by inheritance, while about $50 \%$ are appointed by the traditional ruler after consultation with the subjects and reigning members of the Council of Elders, the Kwihfoyn. Tradition has it that the successor to the throne had to be groomed in the tools of governance by members of the Council of Elders for upwards of nine months. Respondents in the study indicated that during this grooming period, the chief is acquainted with the type of issues the ruler will be called upon to handle: $79 \%$ of them having to do with land/farmer grazier problems, $9 \%$ probate, $7 \%$ witchcraft etc. A near-unanimous $97 \%$ of respondents state that the chief is effectively answerable and accountable to the Council. If the appointed successor was too young to rule, he was assisted by a trusted member of the Council (backed by his peers) who at all times will edify him on all sides of each issue before suggesting a decision, which the ruler would then take in his name. Moreover, respondents state that the Council, with the traditional ruler, provide representation and are an embodiment of stability, which reassures the people of the future peace of the locality. As a matter of fact, respondents here state that $79 \%$ of successors to the throne were chosen by the deceased/last traditional ruler.

On the other side of these elders is the representative of modern authorities. The latter consults the Counxcil and takes the final decision. Even though this personality may be alien to local laws and customs, appointments that the latter makes that are based on the objective advice of the elders have stood the test of time, and the exercise has marked a good symbiosis between the modern and the traditional working together. There has, however, been social upheaval where chiefs have sought to impose the ruling party's ideology (Fisiy 1995: 59; Jua 1995: 45) or where the voice of the people (as expressed through the Council of Elders) has been ignored. ${ }^{10}$

\section{Traditional authorities are 'auxiliaries of the administration'}

The 1977 decree empowered traditional authorities as 'auxiliaries of the administration'. If, prior to 1996, it was obvious that traditional authorities were "auxiliaries of "unitary and centralised administration", it is not so clear today that local authorities (regions and councils) are also institutions of 'administration', albeit local. Traditional authorities under the law were auxiliaries of the administration of the unitary centralized state that were deconcentrated into provinces, divisions and subdivisions. Ambiguity now is 
rife because the territorial scope of the powers of chiefs as organized by the 1977 decree. However, the authority of certain chiefs extends beyond councils, subdivisions, divisions and even provinces. And (as will become obvious subsequently), decentralized modern authorities (incarnated in councillors and members of Parliament), for example, concede that they cannot effectively operate without traditional authorities. Consequently, it is either conceded that the 1977 decree is obsolete or traditional authorities are at the crossroads of modern/local authorities, especially because the Cameroon Constitution of 1996 is silent on the status of traditional authorities.

De jure, the administrative functions performed by traditional authorities essentially have to do with guiding the people. Traditional authorities have the dialogue/communication duty of transmitting directives of administrative authorities to their subjects. They also administer justice according to native laws and customs, where litigation involves subjects of the traditional ruler. In other words, the decree of 1977 (sections 20-21) further empowers traditional authorities with judicial responsibility. Traditional authorities assist in the collection of taxes and fees for the state and local authorities as well as ensure that law and order are respected. Again they are expected to carry out such other duties as are assigned to them by the local administrative authority.

The law therefore implicitly assigns traditional authorities with governance roles. The implications of the exercise of these roles are profound. Subjecting citizens to some other rules than modern law in a republic is implicit concession by republican authorities that the citizen obeys and is bound both by modern law and their native laws and customs (cf. Mamdani 1996). It is difficult to capture the 'republic' in Cameroon that is devoid of this reality. So relegating traditional power to the past because of its origins so as to see 'politics' and power only from the purview of the West, as Kamto (1999) suggests, is to fatally ignore the context in which the Western pattern of the 'the republic' is exercised in Cameroon. The foregoing analysis shows, on the contrary, that traditional authorities serve the common good, res publica. The law endows them with roles, as has been seen, and traditional authority seems to be unavoidable in matters of effective local development.

\section{Traditional authority is at the centre of local development}

Common interest epitomized in local development seems to be a common denominator of the essence of traditional authority, governance and the republic. 'Common interest regulates their concerns and forms their laws and the laws which common interest ordains, have a greater influence than the laws of government' (Paine 1792: 78). Governance is today perceived and understood as fundamentally one of power relations and the different 
ways in which power is exercised for development. It is submitted that the common good, which constitutes the essence of the republic, has competence and efficacy as key and is at the centre of the delivery of public services.

Traditional authorities are at the centre of local development and, as such, are educators of the local population on matters of local development. They are advisers of local councils on the priority development problems of the area. So, traditional authority links the local with the national/global and through cooperation and partnership with modern authorities and institutions. Respondents to this study are unanimous that traditional authorities are institutions that serve councils to attain their development objectives. They help identify priority development needs of the people. Indeed, Mayor Muffi of Tubah Municipality, a respondent to the questionnaire survey of this study, stated that the council

cannot reach the people without passing through traditional authority. Councils are modern authorities that must deliver development to the people or be sanctioned by the people. Councils cannot work effectively without the collaboration of the traditional authority.

Other strengths of traditional authority are those of communication for development, sensitization and mobilization of community effort for development after projects have been approved by Parliament. Traditional authorities constitute the most appropriate channel for transmitting information from modern authorities to the villagers, especially because, in the rural setting, the oral culture of communication remains the most reliable and most used. This specificity raises problems of the medium of communication and of the credibility of the communicating authority. First, development information that is destined for the grassroots that passes through traditional authorities permits ownership by the latter. Secondly, this information leaves the palace of the traditional ruler to the people in the local dialect with which the majority of the masses easily identify. This is unlike modern authority that relies on the written medium for communication, which is carried out either in English or in French. Contrary to the thinking of underdevelopment and dependency theorists (like Harneit-Sievers 1998) who doubt the mobilizational potency of traditional authorities, most of the respondents further stated that there was no better way of mobilizing/sensitizing the local population in favour of development than through traditional authority. The latter have authority to order the people to come out and join in development in language that is not alien to the population. Traditional authorities complement rather than compete with modern authorities. 
All the councillors and members of Parliament involved in this study state that traditional authority is consulted for the identification of priority development needs of the area. Asked whether modern authorities feel bound by the law to consult and use traditional authorities in matters of development, $82 \%$ of them stated that customary law bound them so to do as subjects of the traditional ruler (whose subjects elected the modern authorities into power); $10 \%$ stated that they consult and rely on traditional authority for reasons of efficacy, while $8 \%$ stated that they did so out of respect because traditional authorities are auxiliaries of the administration.

The foregoing are noble functions that normally should not leave traditional authorities at the crossroads of constitutional reform. The traditional authorities, however, are creating what has been referred to by Onibon et al. (1999) as ;sterile dualism'. The reason is that local authorities, like councils, are, for example, empowered by law with the task of local development but it is not they who are effectively operative either for the state or for local inhabitants. On the other hand, traditional systems remain the frame of reference for rural inhabitants in their day-to-day involvement in national life.

\section{Conclusion: Traditional authority is at the crossroads}

Findings of the pilot study are based on traditional authority in centralized society in (a multi-ethnic country that also has traditional authorities created by law to govern in those parts of the nation that are segmentary). Whether centralized or acephalous, what these societies today have in common is the regulation by (and uniformity under the) law of traditional authority. The law endows local councils to take charge of local development. This study shows that traditional authority here is complementary to the modern authority in matters of local governance in the republic in the kind of support they provide to local councils. Without formally integrating traditional authority into the realm of republican institutions, however, legislation only recognizes this by endowing traditional authorities with roles that exemplify the UNDP vision of governance seen earlier. Outstanding in the legislation and pilot study findings are questions of succession, the effectiveness of the Council of Elders as an instrument of accountability in the traditional setting (that republican institutions seem to lack) and the attempted organization of chiefdoms through linkage to territory. These three factors are benchmarks that leave traditional authority at the crossroads of governance in the republic.

First, it is clear that Legislative organisation of traditional authority by territorialization under the 1977 decree seems ill-adapted to the realities of the extraterritoriality of traditional power. As has been demonstrated, traditional authority follows subjects wherever they are because of their ethnic and cultural foundations. Territorialization should therefore be a tool for identifying 
the ethnic origins of a people rather than of circumscribing the geographical scope of a traditional ruler's powers. From this perspective, territorialization becomes an inclusive and not a divisive tool of governance within the republic.

Furthermore, current legislation on the method of access to traditional authority seems to be a middle-of-the-road solution. Neither are questions of succession to traditional authority entirely governed by local laws and customs, nor are they by modern law; the situation is an incomplete mix of both with pros and cons. It is submitted that the dispositions governing succession and access to traditional authority constitute a well-intended approach by republican institutions to modernize access to the same. The 'obligatory' consultation of the Council of Elders prior to the appointment of the chief gives representative 'voice' to the people akin to representation under republican values. The problem, however, is that public officials alien to local culture are endowed by the same disposition with the final decision to choose traditional rulers, and the appeals procedure against their decisions seems flawed. This has often given rise to deliberate or fortuitous disrespect for customary and cultural precepts on the subject and in turn provided a perfect recipe for riots. ${ }^{11}$

Additionally, in the appeals procedure, the official responsible for appointment is both judge and jury, to the exclusion of the Council of Elders who were consulted prior to the appointment. This is even less transparent, especially considering that respondents to the pilot study charge that one major weakness of Cameroonian republican institutions today is the absence or ineffectiveness of its instruments of accountability. It is feared that if present trends continue, traditional authority will eventually reflect the current weaknesses of republican institutions over questions of accountability and graft. Considering the relative advantage of stability and security that traditional authority is said to provide the people as against the republican, it is suggested to leave questions of the mode of accession to traditional power to recognized traditional Council of Elders entirely. Perhaps if traditional authorities per region with common cultures were structured, they could be better arbiters in matters of overseeing questions and problems of succession of their kith and kin than those who are total strangers to the culture.

This study also shows that the public good is a common denominator that underlies governance in the republic and under traditional authority. Under the decentralization laws, local councils have local development as their primary responsibility. Traditional authorities expressly have no place under the decentralization laws. Though qualitative research needs to buttress these quantitative findings irrefutably, the results show that the input of traditional authorities in local development is immensely valuable. Yet the recent 
constitutional reform of 1996 is silent on the future role of traditional authorities within the republic, while leaving the patently deficient 1977 decree in place. Colonialism did not wipe out traditional authorities in Cameroon. It is doubtful that republican precepts and democracy are capable of annihilating traditional authority either.

Traditional authority embodies social norms within ethnic communities. Because people who belong to these ethnic groups have internalized the social norms, there is a minimum level of effort in directing development behaviour in these communities. This facilitates good governance. So it is suggested to accommodate traditional institutions formally and most especially in view of the local development role that this study establishes as played by them and perceived and attested by other actors in local development. Traditional authorities should be formally integrated into the republican institutional setting by effectively constituting the first level of decentralized institutions of local governance rather than being left in limbo as is the case now. The laws of the state have to be aligned with social norms to ensure participation by the larger population, and to promote development. Undervaluing the dynamism of social or customary/traditional values in a country with a rich ethnic background like Cameroon has tended to produce undesired outcomes, such as corruption, bad governance, and so on, to the detriment of the development of the nation. A way forward is to formally integrate traditional authorities into republican institutions.

\section{Notes}

1. Quoted by Tohnji Sama Walters, thesis, n. 51, p. 4.

2. See also Les Droits de l'homme (1791-2) by B. Vincent (reprinted by Presses Universitaires de Nancy), p. 172

3. Benjamin Constant, Principes applicables a tous les gouvernements (reprinted by Droz, Geneva, 1980), p. 80 quoted by Kamto. The translation is the author's.

4. Maximilien Robespierre, Discours du 13 juillet 1791, in Oeuvre, Vol. II, Discours, 2e Partie (Paris, 1962), p. 552. The translation from French to English is the author's.

5. Quoted by Kamto, p. 186.

6. International Crisis Group, Preliminary Report: Governance in post-conflict settings, literature review (March 2006), p. 3 (unpublished).

7. Arrêté No. 224 du 4 février 1933 fixant le statut des chefs indigènes, Journal Officiel du Cameroun 1933, p. 92 (updated as at 31 décembre 1950).

8. Cameron Law No. 96/06 of 18 January 1996.

9. Cameroon National Assembly Report No. 563 of the Second Legislative Period. Legislative Year 1979/80 First Ordinary Session, Report presented on behalf of the Committee on Constitutional Laws, Justice, Legislation and Standing Orders by the Rt Hon. El Hadj Moussa Madi (Member of Parliament) on Bill No. 160/ 
PJL/AN relating to disputes arising from the appointment of traditional rulers, p. 4.

10. Ibid: p. 3. Author's note: This reasoning is questionable. It gives the impression that these authorities were hitherto not 'public institutions'. It is submitted, however, that the Honourable Minister was by that statement intimating that the introduction of democratic rule after colonization brought traditional authorities into the fold of 'public' institutions of governance.

11. One such example is the recent case of an allegedly appointed and corrupt traditional ruler who died by roasting at the hands of his subjects in 2006 and who was said to be the favourite of republican authorities at the expense of the known and legitimate Crown Prince: 'Mutations' 1779, 10 November 2006, p. 5 'L'analyse: Chefferies en péril'.

\section{Acknowledgements}

The author wishes to record his thanks to Franklin Ngwa (sociologist) and Amos Gwei Budzi for assisting in data collection. and to Professor Fondo Sikod of the Faculty of Management and Economic Sciences of the University of Yaoundé II at Soa for very useful comments made on the initial draft of this paper.

\section{Bibliography}

\section{Laws, decrees, orders and parliamentary reports}

Arrêté No. 224 du 4 février 1933 fixant le statut des chefs indigénes (JOC, 1933, p. 92, mis à jour au 31 décembre 1950).

Decree No. 77/245 of 15 July 1977 to organize chiefdoms: Gazette de la République Unie du Cameroun, $1^{\text {er }}$ août 1977.

Cameroon National Assembly Report No. 563 of the second legislative period. Legislative Year 1979/80 First Ordinary Session, Report presented on behalf of the Committee on Constitutional Laws, Justice, Legislation and Sttanding Orders by El Hadj Moussa Madi (MP) on Bill No. 160/PJL/AN relating to disputes arising from the appointment of traditional rulers.

Cameroon Law No. 96/06 of 18 January 1996 on the Constitution.

Law No. 2004/17 of 22 July 2004 on the orientation of decentralization.

Law No. 2004/18 of July 2004 to lay down rules applicable to councils.

Law No. 2004/19 of July 2004 to lay down rules applicable to regions.

\section{Works, articles and other sources}

Abdoul, M., 1996, 'Les communes dans le processus démocratique: la quête difficile d'un pouvoir local électif en Mauritanie', Africa Development 21(4): 75-92.

Azarya, Victor and Chazan, Naomi, 1987, 'Disengagement from the State in Africa: Reflections from the experience of Ghana and Guinea', Comparative Studies in Society and History 29(1) (January). 
Batley, Richard, 2002, 'The Changing role of the state in development', in Desai, V. and Potter, R.B. (eds), The Companion to Development Studies, London: Arnold.

Beall, Jo, 2005, Funding Local Governance: Small grants for democracy and development, ITDG Publishing, Department for International Development.

Beridogo, B., 1997, 'Processus de decentralisation au Mali et couches sociales marginalisés', APAD Bull.14.

Chambers Twentieth Century English Dictionary, Edinburgh: Harrap.

Cheema, D.S. and Rondinelli, D.A. (eds), 1983, Decentralisation and Government, Beverley Hills, CA: Sage.

Charlick, Robert, 1992, The Concept of Governance and Its Implications for USAID's Development Assistance Program in Africa, Washington, DC: USAID.

Chazan, Naomi, 1994, 'Engaging the state: Associational life in Sub-Saharan Africa', in Migdal, Joel S., Kohli, Atul and Shue, Vivienne (eds), State Power and Social Forces: Domination and transformation in the Third World, Cambridge: Cambridge University Press.

Chem-Langhee, B., 1983, 'The Origins of the Southern Cameroons House of Chiefs', International Journal of African Historical Studies 16(4): 653-673.

Constant, Benjamin, 1980, Principes applicables à tous les gouvernements, reprinted Génève: Droz.

Cooter, Robert, 1996, 'The rule of state law and the rule-of-law state', in Bruno, Michael and Pleskovic, Boris (eds), Annual World Bank Conference on Development Economics, Washington, DC: World Bank.

Crowther, Michael and Obaro, Ikime (eds), 1970, West African Chiefs: Their changing status under colonial rule and independence, New York: African Publishing Co.

Doornbos, Martin, 2001, “'Good Governance': The rise and decline of a policy metaphor?”, The Journal of Development Studies 37(6).

Doornbos, Martin, 2002, 'State collapse and fresh starts: Some critical reflections', Development and Change 33(5).

Les Droits de l'homme (1791-2) by B. Vincent, reprinted Nancy: Presses Universitaires de Nancy.

Ekeh, Peter, 1975, 'Colonialism and the two publics in Africa: A theoretical statement', Comparative Studies in Society and History 17(1): 91-112.

Elong Mbassi, Jean Pierre, 1994, 'Avant propos à La décentralisation en Afrique de l'Ouest', Actes du séminaire de Ouagadougou, 5-8 avril 1994, Cotonou: PDM.

Evans, Peter, Rueschemeyer, Dietrich and Skocpol, Theda (eds), 1985, Redefining Political Sociology: Bringing the state back in, Cambridge: Cambridge University Press.

Fisiy, C.F., 1995, 'Chieftaincy in the modern state: An institution at the crossroads of democratic changei', Paideuma 41: 49-62.

Gardinier, D.E., 1963, Cameroon: United Nations Challenge to French Policy, Oxford: Oxford University Press. 
Geschiere, P., 1993, 'Chiefs and colonial rule in Cameroon: Inventing chieftaincy, French and British style', Africa 63(2): 151-175.

Harneit-Sievers, A., 1998, 'Igbo traditional rulers: Chieftaincy and the State of Southeastern Nigeria', Afrika Spectrum 33(1): 57-79.

Hyden, Goran, Court, Julius and Mease, Kenneth, 2005, 'Making Sense of Governance: the need for involving local stakeholders' (unpublished presentation).

International Crisis Group, 2006, 'Preliminary Report: Governance in post-conflict settings, literature review’ (March) (unpublished).

Jua, Nantang, 1995, 'Indirect rule in colonial and post colonial Cameroon', Paideuma 41:39-47.

Kamto, Maurice, 1999, Dechéance de la Politique, Yaoundé: ed. Mandara.

Lagmani, Slim, 1997, 'Le concept de République dans la pensée occidentale', in La Républque, Actes du Colloque de Tunis des 2-3 décembre 1994, Tunis: CPU.

Le Vine, V.T., 1964, The Cameroons: From mandate to independence, Berkeley: University of California Press.

Madison, James, 1961, The Federalist No. 10 (1787), 77-84, ed. Clinton Rossiter, US.info.state.gov/usa/infousa/facts/democrat/

Mamdani, Mahmood, 1996, Citizen and Subject: Contemporary Africa and the Legacy of Late Colonialism. Princeton: Princeton University Press.

Martinussen, John, 1997, Society, State and Market: A guide to competing theories of development, London: Zed Books.

Migdal, Joel S., 1988, Strong Societies and Weak States: State relations and state capabilities in the Third World, Princeton: Princeton University Press.

Migdal, Joel S., 2001, State in Society: Studying how states and societies transform and constitute one another, Cambridge: Cambridge University Press.

Mouiche, I., 1992, 'Les autorités traditionnelles dans la vie politique moderne au Cameroun: le cas de l'organisation municipale du Noun', thesis (unpublished) for a Doctorat de $3^{\mathrm{e}}$ Cycle en science politique, Université de Yaoundé.

Mouiche, I., 1997, 'Le Royaume de bamoun, les chefferies bamiléké et l'Etat au cameroun', in P.N. Nkwi and Nyamnjoh, Francis (eds), Regional Balance and National Integration in Cameroun: Lessons learned and the uncertain future, Yaoundé: ASC/ICASSRT, pp. 306-322.

Mutations, 2006, edition 1779, 10 novembre, http://www.quotidienmutations.net

Nack, Mback, Charles, 2000, 'La chefferie traditionnelle au Cameroun: ambiguités juridiques et dérives politiques', Africa Development XXV(3 and 4).

Nkwi, Paul Nchoji, 1976, Traditional Government and Social Change: A study of the political institutions among the Kom and the Cameroon Grassfields, Fribourg: The University Press.

Nkwi, Paul Nchoji, 'Cameroon Grassfield chiefs and modern politics', Paideuma 25: 99-115.

Nyamnjoh, Francis, 2002, 'Might and Right: Chieftaincy and Democracy in Cameroon and Botswana', Paper prepared for CODESRIA's 10th General Assembly on Africa in the New Millennium, Kampala, Uganda, 8-12 December. 
Onibon, A., Dabire, B. and Ferroukhi, L., 1999, 'Local practices and the decentralisation and devolution of natural resource management in Frenchspeaking West Africa: Stakes, challenges', www.fao.org/docrep/x3030e/ x3030e08.htm

Osaghae, Eghosa E., 2006, 'Colonialism and civil society in Africa: The perspective of Ekeh's two publics', Voluntas: International Journal of Voluntary and Nonprofit Organizations 17(3): 233-245.

Osborn's Concise Law Dictionary, 1976, 6th edn, London: Sweet \& Maxwell.

Sisk, Timothy D. (ed.), 2001, Democracy at the Local Level: The international IDEA Handbook on participation, representation, conflict management and governance, IDEA Handbook Series 4.

Tohnji, Tikum Sama Walters, 2006, 'Chiefs (traditional rulers) in Anglophone Cameroon and modern governance 1961-2000', PhD thesis (unpublished).

UNDP, 1995, UNDP Priorities in Support of Good Governance.

UNDP, 1997, Governance for Sustainable Human Development.

UN ESCAP, 2004, What Is Good Governance?

Weber, Max: Extracts from Max Weber (chapter 3, page 328): www.mdx.ac.uk/ WWW/STUDY/

World Bank, 1992, Governance and Development, Washington, DC; World Bank. World Bank, 1994, Adjustment in Africa: Reforms, results and the road ahead. A World Bank Policy Research Report. New York: Oxford University Press. 
